Review

\title{
Efficacy of sonohysterography and hysteroscopy for evaluation of endometrial lesions in tamoxifen treated patients: a systematic review
}

\author{
Federica Di Guardo ${ }^{1, *}$, Giosuè Giordano Incognito ${ }^{1}$, Chiara Lello $^{2}$, Gisella D’Urso ${ }^{1}$, \\ Fortunato Genovese ${ }^{1}$, Marco Palumbo ${ }^{1}$ \\ ${ }^{1}$ Department of General Surgery and Medical Surgical Specialties, University of Catania, 95125 Catania, Italy \\ ${ }^{2}$ Department of Drug and Health Sciences, University of Catania, 95125 Catania, Italy \\ *Correspondence: fediguardo@gmail.com (Federica Di Guardo) \\ Academic Editor: Enrique Hernandez \\ Submitted: 20 October 2021 Revised: 2 January 2022 Accepted: 5 January 2022 Published: 15 February 2022
}

\begin{abstract}
Objective: This review aims to evaluate the incidence of endometrial lesions in tamoxifen-treated breast cancer patients identified by hysteroscopy (HS) and sonohysterography (SIS) and the diagnostic accuracy of the two methods to detect them. Methods: A systematic review of the literature concerning the role of HS and SIS for evaluation of the endometrium in tamoxifen-treated breast cancer patients was performed. We searched MEDLINE (PubMed), EMBASE, Cochrane Central Register of Controlled Trials, IBECS, BIOSIS, Web of Science, SCOPUS, congress abstracts, and Grey literature (Google Scholar; British Library). The search terms used were "hysteroscopy", "hysterosonography", "sonohysterography" combined with "tamoxifen"; 89 citations were identified and selected in the initial screening. Results: 28 studies were included in the systematic review. There were 61 citations excluded because they were review articles $(\mathrm{n}=$ $9)$ or case report $(n=5)$ and non-English articles $(n=8)$, and had too little information in the full text $(n=39)$. Similar accuracy between SIS and HS in detection of endometrial tamoxifen-related lesions was found. Conclusions: SIS may represent a minimally invasive, simple, safe, well-tolerated and cost-effective alternative to HS, associated with few contraindications and no potential complications.
\end{abstract}

Keywords: Hysteroscopy; Hysterosonography; Sonohysterography; Tamoxifen; Breast cancer

\section{Introduction}

Tamoxifen is a nonsteroidal selective estrogen receptor modulator that is widely used for the treatment of estrogen receptor-positive breast cancer patients [1,2]. Clinical trials have shown that long-term therapy for at least 5 years, is more effective than short-term treatment $(<2$ years). Although it acts as an antiestrogen in breast tissue [3], it has a partial agonist effect on other tissues, such as the endometrium and myometrium [4]; hence, prolonged therapy is associated with various uterine pathologies, including endometrial polyps, submucosal leiomyomas, endometrial hyperplasia, and endometrial cancer [5-8]. However, literature background showed that the benefits achieved in breast cancer treatment, may overcome any potential uterine abnormalities that may occur [9]. In this scenario, it is emerging the necessity to develop adequate methods to diagnose endometrial complications. Nevertheless, the optimal method of surveillance has not yet been determined [6,9-11].

Transvaginal sonography (TVS) is the imaging technique of choice for first-line investigation of intrauterine abnormalities [12-14]. This procedure is relatively painless, well accepted by patients, and can be easily performed by the gynecologist at a relatively low cost [15]. Nevertheless, several studies reported a limited value of TVS in tamoxifen-treated patients due to false-negative [16] as well as false positive results $[10,15]$ and proposed addi- tional diagnostic procedures, such as hysteroscopy (HS) or transvaginal saline infusion sonohysterography (SIS).

HS, combined with histological examination of an endometrial aspiration or biopsy, remains the current gold standard for uterine cavity assessment [16-19]. Moreover, it represents a highly effective therapeutic approach to treat various conditions [20] and it can be useful to assess their eventual recurrence [21]. However, discomfort due to anatomical impediments may represent a cause of office hysteroscopy failure, requiring the necessity for anesthesia and operating theater [22]; a fact that increases both risks and costs. Furthermore, it should be performed by a gynecologist with enough facilities and expertise [23].

In the last 20 years, several studies have proposed the use of SIS, as a less invasive alternative to HS [22,23]. Indeed, it is an affective "add-on" to TVS which involves the use of slow instillation of sterile saline solution into the endometrial cavity through a 5-French catheter under continuous TVS guidance, providing both a contrast medium and an expanding agent [24]. Along this line, sensitivity, specificity, and predictive values of SIS are clearly superior in comparison to TVS. Moreover, SIS is associated with minimal discomfort and lower costs, being easily performed by most of gynecologists [25-29]. With regards to contraindications, only few has been reported in literature [30] eventually leading to no potential complications. Finally, it can accurately differentiate focal lesions such as polyps and 
submucous fibroids [31,32] from diffuse lesions like hyperplasia and cancer [26,30]. Conversely, although the use of HS in detection of intrauterine alteration has widely gained a strong agreement [33], there is a trend towards encouraging the use of SIS as primary method to detect endometrial abnormalities also related to tamoxifen use [32-39].

Given this, the aim of the current review is to evaluate the incidence of endometrial diseases in tamoxifen-treated breast cancer patients identified by HS and SIS and the diagnostic accuracy of the two methods to detect them.

\section{Material and methods}

\subsection{Data sources}

A systematic review of the literature concerning the role of HS and SIS for evaluation of the endometrium in tamoxifen-treated breast cancer patients was performed. We searched MEDLINE (PubMed), EMBASE, Cochrane Central Register of Controlled Trials, IBECS, BIOSIS, Web of Science, SCOPUS, congress abstracts, and Grey literature (Google Scholar; British Library). The following keywords were used: "hysteroscopy", "hysterosonography", "sonohysterography". These terms were further combined with "tamoxifen".

\subsection{Screening of abstract for eligibility}

According to all Authors, the inclusion or exclusion of studies were established at first. Two investigators (F.D.G. and G.G.I.) screened abstracts and titles of the research. A third investigator (G.D.) screened the abstract and the title in case of disagreement.

\subsection{Study selection and eligibility criteria}

The main criteria selection of the literature were original article and clinical trials conducted on human. Only papers written in English were included. Case report and review of the literature were disregarded.

Our systematic search strategy identified a total of 222 citations, after screening of abstracts and titles and removal duplicates, 89 records were identified and selected, finally 28 studies were included in the systematic review (Fig. 1). There were 61 citations excluded because they were review articles $(n=9)$ or case report $(n=5)$ and non-English articles $(\mathrm{n}=8)$, and had too little information in the full text $(\mathrm{n}=$ 39). The selection process of suitable studies is displayed in Fig. 1.

\section{Results}

The incidence of endometrial lesions in tamoxifentreated breast cancer patients identified by HS and SIS, respectively are displayed in Tables 1 (Ref. [11,40-57]) and 2 (Ref. [58-63]). The mean incidence of all lesions was $38.7 \%$. $39.7 \%$ of patients had endometrial polyp that was the most common finding. Only 4 studies reported data about submucosal leiomyoma with an incidence ranging
Total number of citations obtained after on-line search $(n=222)$

Citations excluded after reading abstracts and titles $(n=133)$
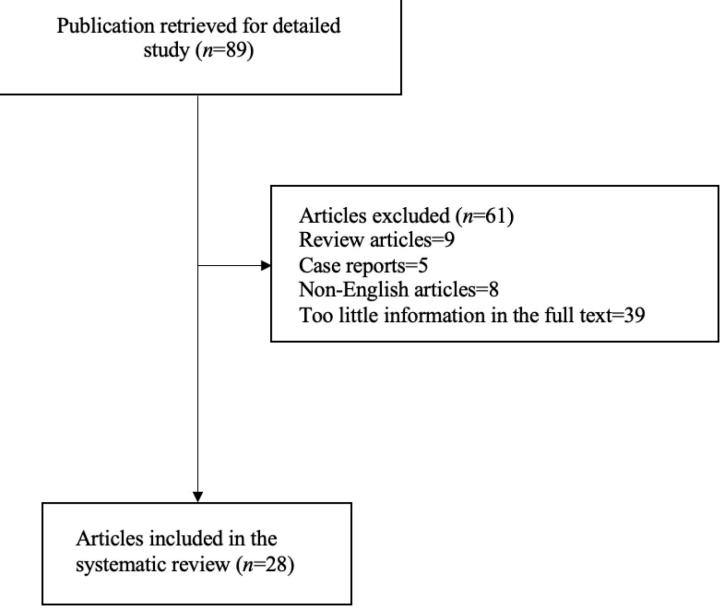

Fig. 1. Selection process for the inclusion of suitable studies for the systematic review. $n$, number.

from $1.7 \%$ to $4.5 \%$. The second most common finding was endometrial hyperplasia (mean incidence of $6 \%$ ). Finally, $3 \%$ of patients had endometrial cancer.

Sensitivity, specificity, positive predictive value (PPV), negative predictive value (NPV) of the two procedures compared to gold standard (which is HS combined with biopsy) are reported in Tables 3 (Ref. [46,56,64-66]) and 4 (Ref. [45,46]). Sensitivity, specificity, PPV, and NPV of SIS were approximately $89,80,76$, and $91 \%$, respectively, whereas HS provided corresponding values of approximately $89,83,66$, and $98 \%$, respectively.

\section{Discussion}

The first large, prospective study showing the association between endometrial cancer and tamoxifen intake was the National Surgical Adjuvant Breast and Bowel Project (NSABP) B-14 trial [6] published in 1994. Subsequent studies showed the incidence of endometrial lesions in tamoxifen-treated breast cancer patients ranges from $15.6 \%$ to $62.2 \%[10,38,44,56,62,65,66]$, in agreement with our mean incidence $(38.7 \%)$.

The long-term endometrial sequels of prolonged tamoxifen treatment necessitate adequate endometrial monitoring for women on tamoxifen therapy. However, what is the most effective and acceptable procedure is controversial [6,9-11]. TVS is widely used for endometrial assessment [13]. Nevertheless, considering that some studies showed a high incidence of false-negative [16] and false positive 


\begin{tabular}{|c|c|c|c|c|c|c|c|c|c|c|}
\hline \multirow{3}{*}{$\begin{array}{l}\text { Study } \\
\text { Ceci et al. } 2000[40]\end{array}$} & \multirow{3}{*}{$\begin{array}{l}\text { Setting } \\
\text { Italy }\end{array}$} & \multirow{3}{*}{$\begin{array}{l}\text { Patients } \\
65 \text { postmenopausal breast cancer patients taking tamoxifen } 20 \mathrm{mg} \text { /day for } 12-72 \text { months with en- } \\
\text { dometrial thickness } \geq 5 \mathrm{~mm} \text { at TVS or AUB }\end{array}$} & \multirow{2}{*}{\multicolumn{2}{|c|}{$\begin{array}{c}\begin{array}{c}\text { Endometrial } \\
\text { polyp }\end{array} \\
(n)(\%)\end{array}$}} & \multirow{2}{*}{\multicolumn{2}{|c|}{$\begin{array}{r}\text { Submucosal } \\
\text { leiomyoma } \\
(n)(\%)\end{array}$}} & \multirow{2}{*}{\multicolumn{2}{|c|}{$\begin{array}{r}\begin{array}{r}\text { Endometrial } \\
\text { hyperplasia }\end{array} \\
\text { (n) }(\%)\end{array}$}} & \multirow{2}{*}{\multicolumn{2}{|c|}{$\begin{array}{c}\begin{array}{c}\text { Endometrial } \\
\text { cancer }\end{array} \\
\text { (n) }(\%)\end{array}$}} \\
\hline & & & & & & & & & & \\
\hline & & & 26 & 40 & 0 & 0 & 11 & 16.9 & 4 & 6.1 \\
\hline Ceci et al. 2003 [41] & Italy & $\begin{array}{l}33 \text { breast cancer postmenopausal patients taking tamoxifen } 20 \mathrm{mg} \text { /day for } 24-68 \text { months with en- } \\
\text { dometrial thickness } \geq 5 \mathrm{~mm} \text { at TVS or AUB }\end{array}$ & 23 & 69.7 & 0 & 0 & 5 & 15.2 & 4 & 12.1 \\
\hline De Muylder et al. 1991 [42] & Belgium & 46 breast cancer patients taking tamoxifen for $6-36$ months & 13 & 28 & 0 & 0 & 8 & 17 & 2 & 4 \\
\hline Dibi et al. 2009 [43] & Brazil & $\begin{array}{l}40 \text { postmenopausal breast cancer patients taking tamoxifen } 20 \mathrm{mg} / \text { day with thickened endometrium } \\
\text { or suggestive of polyps at TVS or AUB }\end{array}$ & 13 & 32.5 & 0 & 0 & 0 & 0 & 0 & 0 \\
\hline Exacoustòs et al. 1995 [44] & Italy & $\begin{array}{l}38 \text { postmenopausal, asymptomatic breast cancer patients taking tamoxifen } 20-30 \mathrm{mg} / \text { day for at least } \\
12 \text { months }\end{array}$ & 19 & 50 & 0 & 0 & 4 & 10 & 0 & 0 \\
\hline Fong et al. 2001 [45] & USA & $\begin{array}{l}117 \text { postmenopausal, asymptomatic breast cancer patients taking tamoxifen } 20-30 \mathrm{mg} / \mathrm{day} \text { for } 13- \\
37 \text { months }\end{array}$ & 45 & 38.5 & 2 & 1.7 & 0 & 0 & 0 & 0 \\
\hline Garuti et al. 2002 [46] & Italy & $\begin{array}{l}98 \text { menopausal breast cancer patients taking tamoxifen } 20-30 \mathrm{mg} / \text { day for } 6-60 \text { months with en- } \\
\text { dometrial thickness } \geq 4 \mathrm{~mm} \text { at TVS }\end{array}$ & 18 & 18 & 0 & 0 & 11 & 11 & 6 & 6 \\
\hline Giorda et al. 2002 [47] & Italy & 310 breast cancer postmenopausal patients taking tamoxifen $20-30 \mathrm{mg}$ /day for at least 6 months & 139 & 44.8 & & & & & & \\
\hline Lahti et al. 1993 [48] & Finland & $\begin{array}{l}49 \text { breast cancer postmenopausal patients taking tamoxifen } 20-40 \mathrm{mg} \text { /day for a mean of } 32 \text { months } \\
\text { (range } 6-95 \text { months) }\end{array}$ & 17 & 35 & 0 & 0 & 0 & 0 & 0 & 0 \\
\hline Le Donne et al. 2013 [49] & Italy & $\begin{array}{l}236 \text { peri/postmenopausal breast cancer patients taking tamoxifen } 20-60 \mathrm{mg} \text { /day for a mean of } 41.1 \\
\text { months with AUB or endometrial thickness at TVS }\end{array}$ & 91 & 38.6 & 0 & 0 & 17 & 7.2 & 7 & 3 \\
\hline Love et al. 1999 [11] & UK & $\begin{array}{l}134 \text { asymptomatic breast cancer patients taking tamoxifen } 20 \mathrm{mg} / \text { day for a mean of } 66 \text { months (range } \\
5-91 \text { months) median 62) with endometrial thickness }>5 \mathrm{~mm} \text { in postmenopausal women and }>8 \\
\mathrm{~mm} \text { in the follicular phase and }>12 \mathrm{~mm} \text { in the luteal phase in premenopausal women at TVS }\end{array}$ & 21 & 15.7 & 6 & 4.5 & 0 & 0 & 0 & 0 \\
\hline Marchesoni et al. 2001 [50] & Italy & $\begin{array}{l}162 \text { postmenopausal breast cancer patients taking tamoxifen } 20 \mathrm{mg} / \text { day for a mean of } 3 \text { years (range } \\
1-5 \text { years) }\end{array}$ & 16 & 9.9 & 6 & 3.7 & 18 & 11.1 & 7 & 4.3 \\
\hline Mourits et al. 1999 [51] & The Netherlands & $\begin{array}{l}22 \text { postmenopausal, asymptomatic breast cancer patients taking tamoxifen } 20-40 \mathrm{mg} / \text { day with en- } \\
\text { dometrial thickness }>5 \mathrm{~mm} \text { at TVS }\end{array}$ & 7 & 45 & 0 & 0 & 0 & 0 & 0 & 0 \\
\hline Neis et al. 2000 [52] & Germany & $\begin{array}{l}33 \text { postmenopausal breast cancer patients taking tamoxifen with endometrial thickness }>8 \mathrm{~mm} \text { at } \\
\text { TVS }\end{array}$ & 18 & 55 & 0 & 0 & 0 & 0 & 0 & 0 \\
\hline Neven et al. 1998 [53] & Belgium & 57 postmenopausal breast cancer patients taking tamoxifen $20 \mathrm{mg} /$ day & 20 & 39.2 & 0 & 0 & 2 & 3.5 & 3 & 5.3 \\
\hline Neven et al. 1990 [54] & Belgium & $\begin{array}{l}16 \text { postmenopausal breast cancer patients taking tamoxifen } 20 \mathrm{mg} / \text { day for a mean of } 17 \text { months (6- } \\
30 \text { months) }\end{array}$ & 4 & 25 & 0 & 0 & 0 & 0 & 1 & 6.2 \\
\hline Pérez-Medina et al. 2011 [55] & Spain & 278 postmenopausal breast cancer patients taking tamoxifen $20 \mathrm{mg} /$ day & 19 & 7.1 & 0 & 0 & 0 & 0 & 5 & 1.7 \\
\hline Saccardi et al. 2013 [56] & Italy & 151 postmenopausal breast cancer patients taking tamoxifen & 38 & 25.2 & 0 & 0 & 1 & 1 & 0 & 0 \\
\hline Teixeira et al. 2007 [57] & Brazil & $\begin{array}{l}25 \text { breast cancer patients taking tamoxifen } 20 \mathrm{mg} \text { /day for a mean of } 3 \text { years (range } 1-7 \text { years) with } \\
\text { endometrial thickness }>5 \mathrm{~mm} \text { at TVS }\end{array}$ & 7 & 28 & 0 & 0 & 4 & 16 & 0 & 0 \\
\hline
\end{tabular}


Table 2. Endometrial lesions detected at SIS in the included studies.

\begin{tabular}{|c|c|c|c|c|c|c|c|c|c|}
\hline \multirow{3}{*}{$\begin{array}{l}\text { Study } \\
\text { Bertelli et al. } 2000 \text { [58] }\end{array}$} & \multirow{2}{*}{\multicolumn{2}{|c|}{ Setting Patients }} & \multirow{2}{*}{\multicolumn{2}{|c|}{$\begin{array}{c}\text { Endometrial } \\
\text { polyp }\end{array}$}} & \multirow{2}{*}{$\begin{array}{c}1 \text { Submucosal } \\
\text { leiomyoma }\end{array}$} & \multirow{2}{*}{\multicolumn{2}{|c|}{$\begin{array}{r}\text { Endometrial } \\
\text { hyperplasia }\end{array}$}} & \multirow{2}{*}{\multicolumn{2}{|c|}{$\begin{array}{c}\begin{array}{c}\text { Endometrial } \\
\text { cancer }\end{array} \\
(n)(\%)\end{array}$}} \\
\hline & & & & & & & & & \\
\hline & $\begin{array}{ll}\text { Italy } & 41 \\
& \mathrm{me}\end{array}$ & $\begin{array}{l}\text { postmenopausal, asymptomatic breast cancer, patients taking tamoxifen } 20 \mathrm{mg} / \text { day for a } \\
\text { an of } 13 \text { months (range } 8-25 \text { months) with endometrial thickness }>8 \mathrm{~mm} \text { at TVS }\end{array}$ & 19 & 46.3 & & & & 0 & 0 \\
\hline El Sheikh et al. 2013 [59] & $\begin{array}{ll}\text { Egypt } & 37 \\
& (1-\end{array}$ & $\begin{array}{l}\text { postmenopausal breast cancer patients taking tamoxifen } 20 \mathrm{mg} / \text { day for a mean of } 2.5 \text { years } \\
-4 \text { years) with endometrial thickness }>8 \mathrm{~mm} \text { at TVS }\end{array}$ & 23 & 62 & 0 & 8 & 22 & 0 & 0 \\
\hline Elhelw et al. 1999 [60] & $\begin{array}{ll}\text { Egypt } & 22 \\
& \text { wi }\end{array}$ & $\begin{array}{l}\text { postmenopausal breast cancer patients taking tamoxifen } 20-30 \mathrm{mg} \text { /day for } 12-28 \text { months } \\
\text { th endometrial thickness }>5 \mathrm{~mm} \text { at TVS }\end{array}$ & 10 & 45.5 & & & & & \\
\hline Hann et al. 2003 [61] & USA 51 & breast cancer patients taking tamoxifen with AUB or endometrial thickness $\geq 8 \mathrm{~mm}$ at TVS & 32 & 63 & 2 & 1 & 2 & 0 & 0 \\
\hline Hann et al. 2001 [62] & $\begin{array}{rr}\text { USA } & 46 \\
& (\mathrm{ra}\end{array}$ & $\begin{array}{l}\text { postmenopausal breast cancer patients taking tamoxifen for a mean of a mean of } 2.6 \text { years } \\
\text { nge } 0.2-6 \text { years) with AUB or endometrial thickness } \geq 8 \mathrm{~mm} \text { at TVS }\end{array}$ & 31 & 62 & & & & & \\
\hline McElrath et al. 2000 [63] & $\begin{array}{rr}\text { USA } & 25 \\
& \text { AL }\end{array}$ & $\begin{array}{l}\text { breast cancer patients taking tamoxifen for a mean of } 40 \text { months (range } 11-70 \text { months) with } \\
\text { JB or endometrial thickness } \geq 5 \mathrm{~mm} \text { at TVS or for screening }\end{array}$ & 17 & 68 & & & & & \\
\hline \multicolumn{10}{|c|}{ SIS, sonohysterography; (n), number; (\%), percentage; AUB, abnormal uterine bleeding. } \\
\hline Study & Setting & Patients & & ensitivity & y (\%) Specif & icity & $\%$ PPV & $(\%)$ & NPV $(\%)$ \\
\hline Garuti et al. 2002 [46] & Italy & $\begin{array}{l}98 \text { menopausal breast cancer patients taking tamoxifen } 20-30 \mathrm{mg} / \text { day for } 6-60 \text { months wi } \\
\text { endometrial thickness } \geq 4 \mathrm{~mm} \text { at TVS }\end{array}$ & & 89.2 & & & & & \\
\hline Garuti et al. 2004 [64] & Italy & $\begin{array}{l}176 \text { postmenopausal, breast cancer patients taking tamoxifen } 20 \mathrm{mg} / \text { die for } 6-60 \text { months wi } \\
\text { endometrial thickness } \geq 4 \mathrm{~mm} \text { at TVS }\end{array}$ & & 100 & & 68.9 & 43. & & 100 \\
\hline Jung et al. 2018 [65] & Korea & $\begin{array}{l}46 \text { postmenopausal breast cancer patients taking tamoxifen for a mean of } 27.1 \text { months (rang } \\
13-68 \text { months) with AUB or endometrial thickness } \geq 4 \mathrm{~mm} \text { at TVS }\end{array}$ & & 85 & & 83 & 79 & & 87 \\
\hline Saccardi et al. 2013 [56] & Italy & 151 postmenopausal breast cancer patients taking tamoxifen & & 83.3 & & 99 & 83. & & 99 \\
\hline Timmermann et al. 1998 [6 & 6] Belgium & $\begin{array}{l}37 \text { asymptomatic breast cancer patients taking tamoxifen } 20-40 \mathrm{mg} / \text { day for a mean of } 23 \text { montl } \\
\text { (range } 13-40 \text { months) }\end{array}$ & & 77 & & & 91 & & \\
\hline
\end{tabular}

PPV, positive predictive value; NPV, negative predictive value; HS, sonohysterography; (n), number; (\%), percentage; AUB, abnormal uterine bleeding. 
Table 4. Sensitivity, specificity, PPV, NPV of SIS for endometrial lesions in the included study.

\begin{tabular}{|c|c|c|c|c|c|c|}
\hline Study & Setting & Patients & Sensitivity (\%) & Specificity (\%) & ) PPV (\%) & $\operatorname{NPV}(\%)$ \\
\hline Fong et al. 2001 [45] & USA & $\begin{array}{l}117 \text { postmenopausal, asymptomatic breast cancer } \\
\text { patients taking tamoxifen } 20-30 \mathrm{mg} / \text { day for } 13-37 \\
\text { months }\end{array}$ & 89.7 & 79.2 & 76.1 & 91.3 \\
\hline Garuti et al. 2002 [46] & Italy & $\begin{array}{l}40 \text { postmenopausal, asymptomatic breast cancer pa- } \\
\text { tients taking tamoxifen for a mean of } 20.5 \text { months } \\
\text { (range } 6-50 \text { months) with endometrial thickness } \geq 4 \\
\text { mm at TVS }\end{array}$ & 86 & 83 & & \\
\hline
\end{tabular}

$[10,15]$ findings in tamoxifen-treated patients, most investigators proposed other diagnostic procedures, such as HS or SIS.

Few studies resembling SIS role in the evaluation of uterine cavity of tamoxifen-treated cases have been published. Fong et al. [67] reviewed the spectrum of uterine findings at SIS in women with breast cancer who were undergoing tamoxifen therapy and summarized the features that can help in recognizing each lesion. A polyp appears as an echogenic mass with smooth margins that often has a narrow attachment to the adjacent endometrium and is completely surrounded by fluid and contains cystic areas. A submucosal leiomyoma is seen as a round structure arising from the myometrium with a thin, overlying echogenic endometrium. Diffuse, smooth thickening of the endometrium suggests endometrial hyperplasia. Finally, an irregular inhomogeneous mass or irregular, focally thickened endometrium is highly suggestive of endometrial carcinoma and lack of distensibility of the endometrial cavity has been described as a potential sign. In this scenario, the development of a new system is desirable for classifying uterine lesions on the basis of sonographic findings and estimating the probability of malignancy, similarly to that used for adnexal masses (GI-RADS) [68].

Some studies suggested that SIS has high sensitivity and specificity rates, ranging from $79 \%$ to $100 \%[60,67,69]$. We compared diagnostic accuracy of SIS and HS in distinguish between normal and abnormal endometrium in postmenopausal tamoxifen-treated breast cancer women, founding similar results between the two methods.

Several studies have compared HS with SIS, some of which demonstrated that SIS can detect lesions not seen by HS. Hann et al. [62] found that 5 of 31 endometrial polyps diagnosed using SIS were not confirmed by HS despite their classic appearance. Similar results were shown by Schwärzler et al. [70], who reported that HS missed 2 of 25 polyps detected using SIS. In patients with positive endometrial features by basal SIS, postoperative SIS identified endometrial polyps, which were histologically verified in $16 / 22(72 \%)$ patients. Although the study patients constituted a selected group, the rate of endometrial pathologies, primarily endometrial polyps, was still very high, especially when compared with other documented studies in literature not using SIS [40,46,70,71]. This high rate concurs with the findings of Achiron et al. [72], who performed SIS in a group of 20 tamoxifen-treated patients and identified endometrial polyps in $8(40 \%)$ of them. Bourne et al. [73] also claimed that SIS revealed a higher proportion of polyps in such patients. In 46 patients who had no specific basal endometrial features by SIS, no endometrial polyps were identified by HS. Thus, SIS yielded no false-negative findings, and its accuracy was not significantly different from the accuracy of HS.

Uterine pathologies correlated with tamoxifen intake include endometrial polyps, submucosal leiomyomas, endometrial hyperplasia, and endometrial carcinoma [5-7]. As most endometrial lesions are benign [10,15,74,75], a minimally invasive procedure as SIS may represent an alternative to HS. We showed that endometrial polyps are the most frequent endometrial findings with a mean incidence of $39.7 \%$, in agreement with previous reports in the literature. If tamoxifen-associated polyps are premalignant lesions is still under debate [76,77]. Nevertheless, given the very high prevalence of endometrial polyps and the low prevalence of endometrial cancer compared to these, many studies support the hypothesis that they are not premalignant lesions [78]. To further incentivize the use of a noninvasive approach, some studies referred to the existence of controversies in the risk for endometrial cancer with the use of tamoxifen. In a case-controlled study about the use of this drug in patients with breast cancer, Cook et al. [79] did not find a significant incidence of endometrial cancer with 2 years use. Tandon et al. [69] did not confirm an increased frequency of endometrial cancer as reported by Mourits et al. [51]. Lahti et al. [48], Neven et al. [80], Cohen et al. [81] and all their co-workers observed only a few cases of endometrial cancer, which were not sufficient to demonstrate a clear relationship between it and tamoxifen administration.

Moreover, SIS is virtually devoid of complications [82]. HS complications are rare, but if left unrecognized can become life threatening. The overall complication rate 
of the latter procedure is $0.28 \%$ and uterine perforation is its most common complication $(0.13 \%)$ [83].

Patients undergoing tamoxifen are often those that have been received a surgical treatment for breast cancer and that may probably benefit (also psychologically) of SIS as a less invasive alternative to HS. Timmermann et al. [66] compared the acceptability of the two methods, including 52 patients with breast cancer who had taken tamoxifen and underwent HS and/or SIS. When asked which test patients would prefer to have in the future, $68 \%$ opted for SIS and $21 \%$ opted for HS. Garuti et al. [64], showed that pelvic pain experienced by breast cancer patients taking tamoxifen at HS was not significantly higher than in the group of women underwent SIS, although the trend favors the latest approach.

A study by Saidi et al. [84] showed that the average cost for SIS was $\$ 195$ and the cost for HS was $\$ 675$, concluding that SIS may represent a cost-effective alternative to HS.

In conclusion, long-term tamoxifen use for the treatment of breast cancer seems to be associated with an increased incidence of endometrial polyps, submucosal leiomyomas, endometrial hyperplasia, and endometrial cancer. Adequate monitoring of endometrial response to tamoxifen in these patients is crucial. We showed similar accuracy between SIS and HS in detection of endometrial tamoxifen-related lesions. Along this line, SIS may represent a minimally invasive, simple, safe, well-tolerated and cost-effective alternative to HS, associated with few contraindications and no potential complications.

\section{Author contributions}

FDG was responsible for the main concept. GGI wrote the first draft of the manuscript, is responsible for the tables design. CL and MP contributed to the manuscript review. FG, GGI, FDG, GD contributed to the research of studies suitable for the review. All authors discussed the results and approved the final manuscript.

\section{Ethics approval and consent to participate}

Not applicable.

\section{Acknowledgment}

We express our gratitude to Dr. Maria Cecilia Cerana for the native English language revision.

\section{Funding}

This research received no external funding.

\section{Conflict of interest}

The authors declare no conflict of interest. MP is serving as one of the Editorial Board members of this journal. We declare that MP had no involvement in the peer review of this article and has no access to information regarding its peer review. Full responsibility for the editorial process for this article was delegated to Prof. Enrique Hernandez.

\section{References}

[1] Jordan VC. Long-term adjuvant tamoxifen therapy for breast cancer. Breast Cancer Research and Treatment. 1990; 15: 125136.

[2] Fentiman IS. The endocrine prevention of breast cancer. British Journal of Cancer. 1989; 60: 12-14.

[3] Ferguson SE, Olshen AB, Viale A, Awtrey CS, Barakat RR, Boyd J. Gene expression profiling of tamoxifen-associated uterine cancers: evidence for two molecular classes of endometrial carcinoma. Gynecologic Oncology. 2004; 92: 719-725.

[4] Dallenbach-Hellweg G, Hahn U. Mucinous and clear cell adenocarcinomas of the endometrium in patients receiving antiestrogens (tamoxifen) and gestagens. International Journal of Gynecological Pathology. 1995; 14: 7-15.

[5] Fisher B, Costantino JP, Wickerham DL, Redmond CK, Kavanah M, Cronin WM, et al. Tamoxifen for Prevention of Breast Cancer: Report of the National Surgical Adjuvant Breast and Bowel Project P-1 Study. JNCI: Journal of the National Cancer Institute. 1998; 90: 1371-1388.

[6] Fisher B, Costantino JP, Redmond CK, Fisher ER, Wickerham DL, Cronin WM. Endometrial Cancer in Tamoxifen-Treated Breast Cancer Patients: Findings from the National Surgical Adjuvant Breast and Bowel Project (NSABP) B-14 *. JNCI: Journal of the National Cancer Institute. 1994; 86: 527-537.

[7] Berlière M. Uterine Side Effects of Tamoxifen: a need for Systematic Pretreatment Screening. Obstetrics \& Gynecology. 1998; 91: 40-44

[8] Cohen I, Beyth Y, Tepper R, Figer A, Shapira J, Cordoba M, et al. Adenomyosis in postmenopausal breast cancer patients treated with tamoxifen: a new entity? Gynecologic Oncology. 1995; 58: 86-91.

[9] Barakat RR. Tamoxifen and endometrial neoplasia. Clinical Obstetrics and Gynecology. 1996; 39: 629-640.

[10] Hulka CA, Hall DA. Endometrial abnormalities associated with tamoxifen therapy for breast cancer: sonographic and pathologic correlation. AJR. American Journal of Roentgenology. 1993; 160: 809-812.

[11] Love CD, Muir BB, Scrimgeour JB, Leonard RC, Dillon P, Dixon JM. Investigation of endometrial abnormalities in asymptomatic women treated with tamoxifen and an evaluation of the role of endometrial screening. Journal of Clinical Oncology. 1999; 17: 2050-2054.

[12] Ascher SM, Imaoka I, Lage JM. Tamoxifen-induced uterine abnormalities: the role of imaging. Radiology. 2000; 214: 29-38.

[13] Karlsson B, Granberg S, Wikland M, Ylöstalo P, Torvid K, Marsal $\mathrm{K}$, et al. Transvaginal ultrasonography of the endometrium in women with postmenopausal bleeding-a Nordic multicenter study. American Journal of Obstetrics and Gynecology. $1995 ; 172$ : $1488-1494$.

[14] Goldstein SR, Nachtigall M, Snyder JR, Nachtigall L. Endometrial assessment by vaginal ultrasonography before endometrial sampling in patients with postmenopausal bleeding. American Journal of Obstetrics and Gynecology. 1990; 163: 119-123.

[15] Yildizhan B, Yildizhan R, Ozkesici B, Suer N. Transvaginal ultrasonography and saline infusion sonohysterography for the detection of intra-uterine lesions in pre- and post-menopausal women with abnormal uterine bleeding. The Journal of International Medical Research. 2008; 36: 1205-1213.

[16] Achiron R, Grisaru D, Golan-Porat N, Lipitz S. Tamoxifen and the uterus: an old drug tested by new modalities. Ultrasound in Obstetrics and Gynecology. 1996; 7: 374-378.

[17] Dijkhuizen FPHLJ, Brölmann HAM, Oddens BJJ, Roumen 
RMH, Coebergh JWW, Heintz APM. Transvaginal ultrasonography and endometrial changes in postmenopausal breast cancer patients receiving tamoxifen. Maturitas. 1996; 25: 45-50.

[18] Jurutka PW, Bartik L, Whitfield GK, Mathern DR, Barthel TK, Gurevich M, et al. Vitamin D receptor: key roles in bone mineral pathophysiology, molecular mechanism of action, and novel nutritional ligands. Journal of Bone and Mineral Research. 2007; 22: V2-10.

[19] Di Guardo F, Della Corte L, Vilos GA, Carugno J, Török P, Giampaolino $\mathrm{P}$, et al. Evaluation and treatment of infertile women with Asherman syndrome: an updated review focusing on the role of hysteroscopy. Reproductive BioMedicine Online. 2020; 41: 55-61.

[20] Chiofalo B, Palmara V, Vilos GA, Pacheco LA, Lasmar RB, Shawki $\mathrm{O}$, et al. Reproductive outcomes of infertile women undergoing "see and treat" office hysteroscopy: a retrospective observational study. Minimally Invasive Therapy \& Allied Technologies. 2021; 30: 147-153.

[21] Di Guardo F, Palumbo M. Asherman syndrome and insufficient endometrial thickness: a hypothesis of integrated approach to restore the endometrium. Medical Hypotheses. 2020; 134: 109521.

[22] Genovese F, D’Urso G, Di Guardo F, Insalaco G, Tuscano A, Ciotta L, et al. Failed diagnostic hysteroscopy: Analysis of 62 cases. European Journal of Obstetrics \& Gynecology and Reproductive Biology. 2020; 245: 193-197.

[23] Leone FPG, Carsana L, Lanzani C, Vago G, Ferrazzi E. Sonohysterographic endometrial sampling and hysteroscopic endometrial biopsy: a comparative study. Ultrasound in Obstetrics \& Gynecology. 2007; 29: 443-448.

[24] La Sala GB, Blasi I, Gallinelli A, Debbi C, Lopopolo G, Vinci V, et al. Diagnostic accuracy of sonohysterography and transvaginal sonography as compared with hysteroscopy and endometrial biopsy: a prospective study. Minerva Ginecologica. 2011; 63: 421-427.

[25] Bartkowiak R, Kaminski P, Wielgos M, Bobrowska K. The evaluation of uterine cavity with saline infusion sonohysterography and hysteroscopy in infertile patients. Neuro Endocrinology Letters. 2006; 27: 523-528.

[26] Parsons AK, Lense JJ. Sonohysterography for endometrial abnormalities: preliminary results. Journal of Clinical Ultrasound. 1993; 21: 87-95.

[27] Brown SE, Coddington CC, Schnorr J, Toner JP, Gibbons W, Oehninger S. Evaluation of outpatient hysteroscopy, saline infusion hysterosonography, and hysterosalpingography in infertile women: a prospective, randomized study. Fertility and Sterility. 2000; 74: 1029-1034.

[28] Soares SR, Barbosa dos Reis MM, Camargos AF. Diagnostic accuracy of sonohysterography, transvaginal sonography, and hysterosalpingography in patients with uterine cavity diseases. Fertility and Sterility. 2000; 73: 406-411.

[29] Gaucherand P, Piacenza JM, Salle B, Rudigoz RC. Sonohysterography of the uterine cavity: preliminary investigations. Journal of Clinical Ultrasound. 1995; 23: 339-348.

[30] Jorizzo JR, Riccio GJ, Chen MYM, Carr JJ. Sonohysterography: the next Step in the Evaluation of the Abnormal Endometrium. RadioGraphics. 1999; 19: S117-S130.

[31] Leone FPG, Lanzani C, Ferrazzi E. Use of strict sonohysterographic methods for preoperative assessment of submucous myomas. Fertility and Sterility. 2003; 79: 998-1002.

[32] Ferrazzi E, Leone FPG. Investigating abnormal bleeding on HRT or tamoxifen: the role of ultrasonography. Best Practice \& Research. Clinical Obstetrics \& Gynaecology. 2004; 18: 145156.

[33] van Dongen H, de Kroon CD, Jacobi CE, Trimbos JB, Jansen FW. Diagnostic hysteroscopy in abnormal uterine bleeding: a systematic review and meta-analysis. BJOG: an International Journal of Obstetrics and Gynaecology. 2007; 114: 664-675.

[34] Ahmadi F, Rashidy Z, Haghighi H, Akhoond M, Niknejadi M, Hemat $\mathrm{M}$, et al. Uterine cavity assessment in infertile women: Sensitivity and specificity of three-dimensional Hysterosonography versus Hysteroscopy. Iranian Journal of Reproductive Medicine. 2013; 11: 977-982.

[35] Ayida G, Chamberlain P, Barlow D, Kennedy S. Uterine cavity assessment prior to in vitro fertilization: comparison of transvaginal scanning, saline contrast hysterosonography and hysteroscopy. Ultrasound in Obstetrics \& Gynecology. 1997; 10: 59-62.

[36] Bingol B, Gunenc MZ, Gedikbasi A, Guner H, Tasdemir S, Tiras B. Comparison of diagnostic accuracy of saline infusion sonohysterography, transvaginal sonography and hysteroscopy in postmenopausal bleeding. Archives of Gynecology and Obstetrics. 2011; 284: 111-117.

[37] Bonilla-Musoles F, Raga F, Osborne NG, Blanes J, Coelho F. Three-dimensional hysterosonography for the study of endometrial tumors: comparison with conventional transvaginal sonography, hysterosalpingography, and hysteroscopy. Gynecologic Oncology. 1997; 65: 245-252.

[38] Gumus II, Keskin EA, Kiliç E, Aker A, Kafali H, Turhan NO. Diagnostic value of hysteroscopy and hysterosonography in endometrial abnormalities in asymptomatic postmenopausal women. Archives of Gynecology and Obstetrics. 2008; 278: 241-244.

[39] Tehranian A, Bayani L, Heidary S, Rastad H, Rahimi A, Hosseini L. Diagnostic accuracy of sonohysterography compared to endometrial biopsy in pre-menopausal women with abnormal uterine bleeding. Medical Journal of the Islamic Republic of Iran. 2015; 29: 201.

[40] Ceci O, Bettocchi S, Marello F, Di Venere R, Pellegrino AR, Laricchia L, et al. Hysteroscopic evaluation of the endometrium in postmenopausal women taking tamoxifen. The Journal of the American Association of Gynecologic Laparoscopists. 2000; 7: 185-189.

[41] Ceci O, Bettocchi S, Nappi L, Di Venere R, Pansini MV, Di Fazio F. Comparison of hysteroscopic and hysterectomy findings to assess the diagnostic accuracy of office hysteroscopy in tamoxifen-treated patients with breast cancer. The Journal of the American Association of Gynecologic Laparoscopists. 2003; 10: 392-395.

[42] De Muylder X, Neven P, De Somer M, Van Belle Y, Vanderick $\mathrm{G}$, De Muylder E. Endometrial lesions in patients undergoing tamoxifen therapy. International Journal of Gynaecology and Obstetrics. 1991; 36: 127-130.

[43] Dibi RP, Zettler CG, Pessini SA, Ayub AV, de Almeida SB, da Silveira GPG. Tamoxifen use and endometrial lesions. Menopause. 2009; 16: 293-300.

[44] Exacoustos C, Zupi E, Cangi B, Chiaretti M, Arduini D, Romanini C. Endometrial evaluation in postmenopausal breast cancer patients receiving tamoxifen: an ultrasound, color flow Doppler, hysteroscopic and histological study. Ultrasound in Obstetrics \& Gynecology. 1995; 6: 435-442.

[45] Fong K, Kung R, Lytwyn A, Trudeau M, Chapman W, Nugent $\mathrm{P}$, et al. Endometrial evaluation with transvaginal us and hysterosonography in asymptomatic postmenopausal women with breast cancer receiving tamoxifen. Radiology. 2001; 220: 765773.

[46] Garuti G, Grossi F, Cellani F, Centinaio G, Colonnelli M, Luerti M. Hysteroscopic assessment of menopausal breast-cancer patients taking tamoxifen; there is a bias from the mode of endometrial sampling in estimating endometrial morbidity? Breast Cancer Research and Treatment. 2002; 72: 245-253.

[47] Giorda G, Crivellari D, Veronesi A, Perin T, Campagnutta E, 
Carbone A, et al. Comparison of ultrasonography, hysteroscopy, and biopsy in the diagnosis of endometrial lesions in postmenopausal tamoxifen-treated patients. Acta Obstetricia Et Gynecologica Scandinavica. 2002; 81: 975-980.

[48] Lahti E, Blanco G, Kauppila A, Apaja-Sarkkinen M, Taskinen PJ, Laatikainen T. Endometrial changes in postmenopausal breast cancer patients receiving tamoxifen. Obstetrics and Gynecology. 1993; 81: 660-664.

[49] LE Donne M, Alibrandi A, Ciancimino L, Azzerboni A, Chiofalo B, Triolo O. Endometrial pathology in breast cancer patients: Effect of different treatments on ultrasonographic, hysteroscopic and histological findings. Oncology Letters. 2013; 5: 1305-1310.

[50] Marchesoni D, Driul L, Fabiani G, Di Loreto C, Cataldi P, Mozzanega B. Endometrial histologic changes in post-menopausal breast cancer patients using tamoxifen. International Journal of Gynaecology and Obstetrics. 2001; 75: 257-262.

[51] Mourits MJ, Van der Zee AG, Willemse PH, Ten Hoor KA, Hollema H, De Vries EG. Discrepancy between ultrasonography and hysteroscopy and histology of endometrium in postmenopausal breast cancer patients using tamoxifen. Gynecologic Oncology. 1999; 73: 21-26.

[52] Neis KJ, Brandner P, Schlenker M. Tamoxifen-induced hyperplasia of the endometrium. Contributions to Gynecology and Obstetrics. 2000; 20: 60-68.

[53] Neven P, De Muylder X, Van Belle Y, Van-Hooff I, Vanderick G. Longitudinal hysteroscopic follow-up during tamoxifen treatment. The Lancet. 1998; 351: 36.

[54] Neven P, De Muylder X, Van Belle Y, Vanderick G, De Muylder E. Hysteroscopic follow-up during Tamoxifen treatment. European Journal of Obstetrics \& Gynecology and Reproductive Biology. 1990; 35: 235-238.

[55] Pérez-Medina T, Salazar FJ, San-Frutos L, Ríos M, Jiménez JS, Troyano J, et al. Hysteroscopic dynamic assessment of the endometrium in patients treated with long-term tamoxifen. Journal of Minimally Invasive Gynecology. 2011; 18: 349-354.

[56] Saccardi C, Gizzo S, Patrelli TS, Ancona E, Anis O, Di Gangi $\mathrm{S}$, et al. Endometrial surveillance in tamoxifen users: role, timing and accuracy of hysteroscopic investigation: observational longitudinal cohort study. Endocrine-Related Cancer. 2013; 20: 455-462.

[57] Teixeira AC, Urban LABD, Schwarz RS, Pereira C, Millani TCC, Passos AP. Value of sonographic endometrial findings in patients under tamoxifen therapy. Radiologia Brasileira. 2007; 40.

[58] Bertelli G, Valenzano M, Costantini S, Rissone R, Angiolini C, Signorini A, et al. Limited Value of Sonohysterography for Endometrial Screening in Asymptomatic, Postmenopausal Patients Treated with Tamoxifen. Gynecologic Oncology. 2000; 78: 275-277.

[59] El Sheikh H, Atwa K, Sammour MA. Sonohysterography for evaluation of endometrial abnormalities associated with tamoxifen therapy for breast cancer. The Egyptian Journal of Radiology and Nuclear Medicine. 2013; 44: 953-958.

[60] Elhelw B, Ghorab MN, Farrag SH. Saline sonohysterography for monitoring asymptomatic postmenopausal breast cancer patients taking tamoxifen. International Journal of Gynaecology and Obstetrics. 1999; 67: 81-86.

[61] Hann LE, Kim CM, Gonen M, Barakat R, Choi PH, Bach AM. Sonohysterography compared with endometrial biopsy for evaluation of the endometrium in tamoxifen-treated women. Journal of Ultrasound in Medicine. 2003; 22: 1173-1179.

[62] Hann LE, Gretz EM, Bach AM, Francis SM. Sonohysterography for Evaluation of the Endometrium in Women Treated with Tamoxifen. American Journal of Roentgenology. 2001; 177: $337-$ 342.
[63] McElrath T, Anderson P, Fields A, Somma L, Gross S, Runowicz CD. Saline infusion sonography: a diagnostic and therapeutic intervention for patients on tamoxifen. Obstetrics and Gynecology. 2000; 95.è

[64] Garuti G, Cellani F, Colonnelli M, Garzia D, Gonfiantini C, Luerti M. Hysteroscopically targeted biopsies compared with blind samplings in endometrial assessment of menopausal women taking tamoxifen for breast cancer. The Journal of the American Association of Gynecologic Laparoscopists. 2004; 11: 62-67.

[65] Jung H, Jung JK, Kim SB, Cho EA, Um MJ. Comparative Study on Hysteroscopic and Histologic Examinations of the Endometrium in Postmenopausal Women Taking Tamoxifen. Journal of Menopausal Medicine. 2018; 24: 81.

[66] Timmerman D, Deprest J, Bourne T, Van den Berghe I, Collins WP, Vergote I. A randomized trial on the use of ultrasonography or office hysteroscopy for endometrial assessment in postmenopausal patients with breast cancer who were treated with tamoxifen. American Journal of Obstetrics and Gynecology. 1998; 179: $62-70$.

[67] Fong K, Causer P, Atri M, Lytwyn A, Kung R. Transvaginal us and Hysterosonography in Postmenopausal Women with Breast Cancer Receiving Tamoxifen: Correlation with Hysteroscopy and Pathologic Study. RadioGraphics. 2003; 23: 137-150.

[68] Amor F, Vaccaro H, Alcázar JL, León M, Craig JM, Martinez J. Gynecologic Imaging Reporting and Data System. Journal of Ultrasound in Medicine. 2009; 28: 285-291.

[69] Tandon V, Kapoor B, Gupta A, Gupta G, Khajuria V, Gupta S. Effects of tamoxifen therapy on the endometrium in postmenopausal patients of breast cancer. Indian Journal of Pharmacology. 2006; 38: 289.

[70] Schwärzler P, Concin H, Bösch H, Berlinger A, Wohlgenannt K, Collins WP, et al. An evaluation of sonohysterography and diagnostic hysteroscopy for the assessment of intrauterine pathology. Ultrasound in Obstetrics \& Gynecology. 1998; 11: 337-342.

[71] Tepper R, Beyth Y, Altaras MM, Zalel Y, Shapira J, Cordoba $\mathrm{M}$, et al. Value of Sonohysterography in Asymptomatic Postmenopausal Tamoxifen-Treated Patients. Gynecologic Oncology. 1997; 64: 386-391.

[72] Achiron R, Lipitz S, Sivan E, Goldenberg M, Mashiach S. Sonohysterography for ultrasonographic evaluation of tamoxifenassociated cystic thickened endometrium. Journal of Ultrasound in Medicine. 1995; 14: 685-688.

[73] Bourne TH, Lawton F, Leather A, Granberg S, Campbell S, Collins WP. Use of intracavity saline instillation and transvaginal ultrasonography to detect tamoxifen-associated endometrial polyps. Ultrasound in Obstetrics and Gynecology. 1994; 4: 73 75.

[74] Tamanaha S, Aldrighi JM, Santos RED, Prado RAA. Sensitivity and specificity of hysterosonography in endometrial abnormalities in asymptomatic postmenopausal women. Revista Da Associacao Medica Brasileira (1992). 2004; 50: 427-432. (In Portuguese)

[75] Markovitch O, Tepper R, Aviram R, Fishman A, Shapira J, Cohen I. The value of sonohysterography in the prediction of endometrial pathologies in asymptomatic postmenopausal breast cancer tamoxifen-treated patients. Gynecologic Oncology. 2004; 94: 754-759.

[76] Ascher SM, Johnson JC, Barnes WA, Bae CJ, Patt RH, Zeman RK. MR imaging appearance of the uterus in postmenopausal women receiving tamoxifen therapy for breast cancer: histopathologic correlation. Radiology. 1996; 200: 105110.

[77] Cohen I, Bernheim J, Azaria R, Tepper R, Sharony R, Beyth Y. Malignant Endometrial Polyps in Postmenopausal Breast Cancer Tamoxifen-Treated Patients. Gynecologic Oncology. 1999; 
75: 136-141.

[78] Gerber B, Krause A, Müller H, Reimer T, Külz T, Makovitzky J, et al. Effects of adjuvant tamoxifen on the endometrium in postmenopausal women with breast cancer: a prospective long-term study using transvaginal ultrasound. Journal of Clinical Oncology. 2000; 18: 3464-3470.

[79] Cook LS, Weiss NS, Schwartz SM, White E, McKnight B, Moore DE, et al. Population-based study of tamoxifen therapy and subsequent ovarian, endometrial, and breast cancers. Journal of the National Cancer Institute. 1995; 87: 1359-1364.

[80] Neven P, Shepherd JH, Lowe DG. Tamoxifen and the gynaecologist. British Journal of Obstetrics and Gynaecology. 1993; 100: 893-897.

[81] Cohen I, Rosen DJ, Shapira J, Cordoba M, Gilboa S, Altaras
MM, et al. Endometrial changes with tamoxifen: comparison between tamoxifen-treated and nontreated asymptomatic, postmenopausal breast cancer patients. Gynecologic Oncology. 1994; 52: 185-190.

[82] Goldstein RB. Saline Infusion Sonohysterography. Ultrasound Clinics. 2006; 1: 385-414.

[83] Jansen FW, Vredevoogd CB, van Ulzen K, Hermans J, Trimbos JB, Trimbos-Kemper TC. Complications of hysteroscopy: a prospective, multicenter study. Obstetrics and Gynecology. 2000; 96: 266-270.

[84] Saidi MH, Sadler RK, Theis VD, Akright BD, Farhart SA, Villanueva GR. Comparison of sonography, sonohysterography, and hysteroscopy for evaluation of abnormal uterine bleeding. Journal of Ultrasound in Medicine. 1997; 16: 587-591. 